\title{
Introduction: a tribute to Professor Adam Bartecki
}

\author{
Maria Cieślak-Golonka
}

Published online: 4 December 2009

(C) Springer Science+Business Media, LLC 2009

I am greatly honored and pleased to write this short introduction to the papers collected to celebrate the 90th birthday of the eminent Polish chemist, Professor Adam Bartecki. He was born on 17 March 1920, in Stanislawow, Poland (now Ivano-Frankivsk in the Ukraine). He belongs to the first generation of Poles born and brought up in independent Poland, revived in 1918 after over 120 years of foreign rule. That generation was aware of its living in a free homeland and had a profound sense of responsibility for its freedom, and a consciously positive attitude toward education and hard work. However, the freedom was lost again in 1939, with the outbreak of the Second World War. After the war, in 1945, a great migration of nations followed. He had to leave his home and settled in the western territory of post-war Poland that had belonged to Germany before the war.

He resumed his studies in 1946 that he had begun years before in Lwow (Lemberg), at the University and Technical University of Wroclaw (formerly, Breslau). Until 1951, the two used to be one joint institution of higher learning. He chose chemistry as his major, although he was also interested in other fields, including mathematics and languages. In Wrocław, he studied chemistry under eminent professors, also coming from Lwow, such as Boguslawa Jezowska-Trzebiatowska, Wlodzimierz Trzebiatowski, Blazej Roga, and Wiktor Gorzelany. His first research project concerned the chemistry of coal.

It was soon after the war that he married Krystyna, his wartime acquaintance, the daughter of a Polish army medical doctor. She was a lady of great personality and presence, who later became also a doctor. They had three

M. Cieślak-Golonka ( $\square)$

Department of Chemistry, Wrocław University of Technology,

Wrocław, Poland

e-mail: maria.golonka@pwr.wroc.pl children: Janusz, Małgorzata, and Ewa. He now has four grandchildren.

Adam Bartecki's has had very broad interests in chemistry. $\mathrm{He}$ has worked on topics ranging from the fundamentals of coordination chemistry to its very practical applications, for example in hydrometallurgy. He is also an outstanding expert in electronic spectroscopy, and his ability to choose the right method for the right problem led him to his successful work on color, which he initiated in his 70s. His scientific interests were reflected by the conferences he has organized, including several on the role of the computer in chemistry and on the fundamentals and applications of color. Professor Bartecki has given invited lectures in Leipzig, Jena, Budapest, Brno, Stockholm, and Uppsala, to mention but a few places.

From among his over 300 publications, only a few are mentioned here:

A. Bartecki, K. Kurzak

Colour of $3 d$ transition metal ions. Rev. Inorg. Chem. 2007, 27(5) 319-386

A. Bartecki, W. Apostoluk

Extraction of $\mathrm{VO}^{2}$ and $\mathrm{Fe}^{2+}$ with heptanoic acid in the presence of phen and bpy. Hydrometallurgy, 1995, 37(2) 235-241

A. Bartecki, Z. Staszak

Influence of bulk and $\pi$ donor and $\pi$ acceptor properties of solvent on ligand-field spectra. Spectry. Lett. 1989, 22(9) 1193-1201

J. Myrczek, A. Bartecki, M. Sowinska

Computer application to vibronic spectra including $d-d$ transitions. J. Mol. Struct. 1984, 115, 271-274.

T.Tlaczala, A. Bartecki

Effect of catalyst ion on the course of oscillation reactions in the system: pyrogallol- $\mathrm{KBrO}_{3}-\mathrm{H}_{2} \mathrm{SO}_{4} \mathrm{Z}$. Phys. Chem. 1984, 265(1), 96-100 


\section{S.P. Sinha, A. Bartecki}

Extension of the "Inclined W" concept to the d-transition metal ions. Inorg. Chim. Acta 1978, 31, 77-82

W. Walkowiak, A. Bartecki

Flotation of complex ions of the VIII subgroup. Nukleonika, 1973 18(3) 133-141

B. Jeżowska-Trzebiatowska, A. Bartecki

Fine structure of the electronic absorption spectra of uranyl complexes. Spectrochim. Acta 1962, 18(6) 799

A. Bartecki

On photometric method of the determination of the process of combustion of the solid fuels. Proceed. Scientific Session, Wrocław, 12-14 XII (1952), 101-103

He has promoted 18 doctoral students of whom eight later received their venia legendi (habilitation, that is, the right to lecture at a university), and three of them are now full professors. He is the author of five books. One of them is on transition metal chemistry, which has served as a textbook and has been popular among students and researchers alike. His latest book, The Colour of the Metal Ions, was written jointly with John Burgess, and published by Gordon and Breach in 2000. It demonstrates interests in spectroscopy and color, and is an updated version of his earlier book in Polish. The authors of this monograph, joined by Krzysztof Kurzak, are now preparing an expanded new edition, which will contain a new chapter on the color of nanoparticles, written by Adam Bartecki himself. This illustrates his continuing interest in and enthusiasm toward new aspects of chemistry.

The papers collected in this special issue have been written by his "chemical children and grandchildren" as well as by his longtime friends. Let these contributions be an expression of our gratitude for his inspiration and friendship.

Ad multos annos, Maestro! 